Environment Conservation Journal 20 (1\&2) 15-25, 2019

ISSN 0972-3099 (Print) 2278-5124 (Online)

Abstracted and Indexed

\title{
Treatment of industrial waste water using Water hyacinth (Eichornia crassipus) and Duckweed (Lemna minor): A Comparative study
}

\author{
Bhutiani R., ${ }^{1}$ Rai N., ${ }^{2}$ Kumar N., ${ }^{2}$ Rausa M. ${ }^{2}$ and Ahamad F. ${ }^{1} \bowtie$
}

Received: 29.10 .2018

Revised: 20.01.2019

Accepted: 14.03.2019

\begin{abstract}
As we all know that water is essential to all forms of life and makes up about $70 \%$ of the human body weight. Due to the direct link of water quality with human welfare, the quality of water is of vital concern. Industrialization plays major role in the development of a country's economy. However, these plants and industries generate hazardous by-products and discharge them directly or partially treated into the environment which contaminates the surface water, ground water and soil causing a great threat to the life of human beings, animal and plants. In the present investigation an attempt has been made to identify the potential of water hyacinth (Eichornia crassipus) and Duckweed (Lemna minor) for the treatment of industrial waste water generated from Dehradun industrial area using phytoremediation technology on the basis of different physicochemical parameters such as pH, EC, DO, ORP, Salinity, TDS, BOD, COD, Hardness and Temperature. Eichornia crassipus shows maximum decrease in pH, TDS and COD and Lemna minor shows maximum decrease in EC, ORP, Salinity, BOD and TH. In case of DO maximum decrease was observed in control experiment. During the assessment period Lemna minor was found highly efficient in comparison to Eichornia crassipus. Both water hyacinth (Eichornia crassipus) and Duckweed (Lemna minor) shows maximum removal between $1^{\text {st }}$ to $5^{\text {th }}$ day of treatment but the removal goes down as the experiment proceeds towards the end as the retarded growth of plants was observed due to toxicity of accumulated pollutants inside the palnts.
\end{abstract}

Key words: Eichornia crassipus, Lemna minor, enormous investments, xenobiotics, engineering based remediation.

\section{Introduction}

Water is essential natural element for all kinds of life present on the earth. Due to the direct link of water quality with human welfare, the quality of water is of vital concern. It is unique liquid, without which life is impossible (Bhutiani et al., 2016). Industrialization due to release of untreated and partially treated effluent has become a great threat to the environment. There are a number of reasons the effluents are not treated properly by the industries. Among all one reasons is due to the lack of highly efficient and economic treatment technologies. Due to the rapid urbanization and industrialisation, wastewater has been continuously released in excess amount into the environment, causing significant impacts on human and wild life (Borkar et al., 2013). Both industrial and household Author's Address

${ }^{1}$ Limnology and Ecological Modelling Lab. Department of Zoology \& Environmental Sciences, Gurukula Kangri Vishwavidyalaya, Haridwar - 249404 , Uttarakhand, India.

${ }^{2}$ Department of Biotechnology, Graphic Era (Deemed to be University), Dehradun- 248002, Uttarakhand, India.

E-mail.:faheem.rs@gkv.ac.in wastewater contains a large quantity of chemicals and biological matter that impose a great demand on the oxygen present in water and industrial effluents also contain that are directly harmful to human health and the ecosystem. In recent years due to the urbanization and industrialization, the rate of discharge of pollutant into the environment have been on the increase. During the last fifty years, in India the number of small and large scale industries has grown rapidly. Both in small as well as small scale industries do not have adequate effluent treatment facilities. Most of these defaulting industries are sugar mills, distilleries, pulp and paper mill and leather-processing industries. Small-scale industries, which cannot afford enormous investments in pollution control equipment due to their profit margins, are major producers of contaminated effluent (www.tappi.org/paperu/grow_up/great Career.htm. 2003). The use of phytoremediation technology for the treatment of industrial effluent has become 


\section{Bhutiani et al.}

popular due to its simplicity and low energy energy requirement in comparison to more sophisticated technology (Sooknah and Wilkie, 2004; Padmapriya and Murugesan, 2012; Kumar and Chopra, 2016, Kumar et al., 2016). The term is a combination of two words, phyto (from Greek) which means plant and Latin word remediation which means to remove, which refers the use of plants based technologies to clean the contaminants (Cunningham et al., 1997; Flatman and Lanza, 1998). Phytoremediation is an alternative or complimentary technology that can be used in place of and some timers in combination with mechanical conventional clean-up technologies that often require high capital inputs and labour and energy intensive. Phytoremediation is an emerging, clean, efficient, inexpensive ecological and environment friendly and solarenergy driven clean-up technology, based on the concept of using nature to cleanse nature (UNEP, Undated). Higher plants due to ability for the degradation and metabolism of many recalcitrant xenobiotics, can be considered as "green livers", which acts as an important sink for environment damaging chemicals (Schwitzguebel, 2000). It is a non-invasive alternative technology for engineering based remediation methods (Weis and Weis, 2004). The primary objective for the development of phytoremediation technologies is use the potential of macrophytes for low-cost remediation (Weis and Weis, 2004; Ensely, 2000). The present study has been taken to explore the phytoremediation potential of Eichhornia crassipes (E. crassipes) and Lemna minor (L. minor) in treatment of industrial waste water.

This followed the underlying objectives:-

1. To assess phytoremediation potential of E.crassipes and L. minor in treatment of industrial waste water.

2. To investigate effect of phytoremediation on physico-chemical characteristics of industrial waste water.

\section{Materials and Methods}

Collection of Industrial wastewater: Industrial wastewater was collected from industrial area located at Dehradun. Sampling was carried out in plastic container which was rinsed properly before collecting waste water. $\mathrm{pH}, \mathrm{EC}$, Salinity, ORP, DO, TDS and temperature was measured using Multipara meter system of model No. SensION+ MM 150 (Hach). Each time before taking the reading, calibration of the instrument was done. The measurements were taken at regular intervals of 3 days. Then the sample was carried to the laboratory and stored at $4^{0} \mathrm{C}$ for further analysis. The various physico-chemical parameters including Hardness, BOD, and COD of the wastewater samples were analyzed using standard methods described by APHA, 2012; Trivedy and Goel, 1986; Khanna and Bhutiani, 2008.

Collection of Macrophytes: $E$. crassipes and $L$. minor was collected from a pond located near Ramnagar, Roorkee. Both the macrophytes were collected on the same day and brought to laboratory for experimental setup and plants was thoroughly washed with tap water followed by distill water and finally roots were rinsed with acetone to avoid any contamination.

Experimental Setup: Plastic tubs of round shape of 5litre capacity were selected for starting the experiment. Tubs were properly washed and dried with tissue. All the tubs were filled with the waste water. Container 1 was fixed as a control and it was without any plant. E. crassipes was grown in container 2, and L. minor was put in container 3 . Samples were taken after every 5 days separately from all three tubs and were analyzed for $\mathrm{pH}, \mathrm{EC}$, DO, ORP, salinity, TDS, BOD, COD, Hardness and temperature. This assessment was carried out for 30 days at a regular interval of 5 days.

Eichhornia crassipes (Water hyacinth): $E$. crassipes which belongs to family Pontederiaceae is one of the world's most prevalent invasive aquatic plants. Between water hyacinth and waterhyacinth. "Waterhyacinth" is the most standard spelling approved by the Weed Science Society of America. Approximately 10 to $100 \%$ of existing seeds was observed to germinate within a period of six months, with dry conditions promoting germination (Ueki and Oki, 1979). Nutrients and temperature are the strongest determinants for water hyacinth growth and reproduction (Wilson et al., 2007). Salinity constraints generally limit water hyacinth establishment in coastal areas and within estuaries (Mangas-Ramirez and Elias-Gutierrez, 2004). Low temperatures and winter ice cover currently limit water hyacinth from spreading into 
cooler latitudes (Rodríguez-Gallego et al., 2004). However, recent climate change models suggest that the distribution of aquatic invasive species is likely to expand in temperate regions (Hellmann et al., 2008; Rahel and Olden, 2008). The distribution of water hyacinth is prevalent in tropical and subtropical water bodies because of high nutrient level due to agricultural runoff, deforestation, and insufficient wastewater treatment (Bartodziej and Weymouth, 1995; Brendonck et al., 2003; Lu et al., 2007; Martinez Jimenez \& Gomez Balandra, 2007; Gibbons et al., 1994). Prior research on water hyacinth's effects on water quality was performed by (Rommens et al., 2003; Mangas-Ramirez and Elias-Gutierrez, 2004; Perna and Burrows, 2005; Giraldo and Garzon, 2002; Meerhoff et al., 2003; Troutman et al., 2007; Greenfield et al., 2007). Water hyacinth also absorbs heavy metals (Tiwari et al., 2007), organic contaminants (Zimmels et al., 2007), and nutrients from the water column (Aoi and Hayashi, 1996). The capacity of hyacinth to absorb nutrients makes it a potential biological alternative to secondary and tertiary treatment for wastewater (Cossu et al., 2001; Kumar et al., 2017a, b).

Lemna minor (Duckweed): Lemna belongs to family Lemnaceae is commonly known as duckweed. They commonly grow in stagnant or slow-flowing, nutrient-enriched waters throughout tropical and temperate zones. (Mkandawire and Dudel 2005a, 2005b; Les et al., 2002). Anatomically, they are a diffuse unit known as a frond which is composed of leaflets and a root-like structure. They are also considered as model plant representative of higher plants for a large number of chemical and biogeochemical studies involving regulation of element assimilation in higher plants. Apart from phytoremediation studies Lemna spp. are among the most standardized test organisms in aquatic ecotoxicology (EPA 1996; DIN 2000; Eberius 2001; ISO 2001; OECD 2002).

\section{Results and Discussion}

Physico-chemical characteristics of waste water Before starting the experiments, physico-chemical analysis of waste water was carried out in the laboratory. Waste water was analyzed for $\mathrm{pH}$, temperature, electrical conductivity (EC), oxidation-redox potential (ORP), dissolved oxygen (DO), biochemical oxidation demand $\left(\mathrm{BOD}_{5}\right)$, chemical oxidation demand (COD), salinity, total dissolve solids (TDS), hardness (as $\left.\mathrm{CaCO}_{3}\right)$ (Table $1)$.

Table 1. Physico-chemical characteristics of industrial waste water

\begin{tabular}{|c|c|c|c|}
\hline S.No & Parameter & Unit & Value \\
\hline 1. & $\mathrm{pH}$ & - & 9.6 \\
\hline 2. & Electrical Conductivity (EC) & Micro S/cm & 4009.0 \\
\hline 3. & Oxidation-Redox potential (ORP) & $\mathrm{mV}$ & -151.9 \\
\hline 4. & Total dissolved solids (TDS) & $\mathrm{mg} / \mathrm{L}$ & 2650.0 \\
\hline 5. & Salinity & $\mathrm{mg} / \mathrm{L}$ & 2650.0 \\
\hline 6. & Biochemical oxygen demand (BOD 5$)$ & $\mathrm{mg} / \mathrm{L}$ & 356.26 \\
\hline 7. & Chemical oxygen demand (COD) & $\mathrm{mg} / \mathrm{L}$ & 519.0 \\
\hline 8. & Dissolved oxygen (DO) & $\mathrm{mg} / \mathrm{L}$ & 2.53 \\
\hline 9. & Hardness (as CaCo $\left.\mathrm{Ca}_{3}\right)$ & $\mathrm{mg} / \mathrm{L}$ & 1.84 \\
\hline 10. & Temperature & ${ }^{\circ} \mathrm{C}$ & 24.5 \\
\hline
\end{tabular}

Effects of Macrophyte treatment on wastewater quality: Industrial waste water was treated with $E$. crassipes, and L.minor during the experimental period. Sample was filled in plastic containers (capacity $\quad-5.0 \quad$ litres). Assessment of phytoremediation efficiencies of $E$. crassipes, and L.minor was carried out in 5 assessments periods (Table 2).

Effects of $E$. crassipes and $L$. minor treatments on industrial waste water quality: E. crassipes, and L.minor were grown separately in industrial waste water to assess the phytoremediation efficiency of selected plants in terms of changes in waste water parameters such as $\mathrm{pH}$, 
Bhutiani et al.

Table 2. Details of Assessment number and period for experimental period

\begin{tabular}{|c|c|c|}
\hline S.No. & Assessment number & Assessment period \\
\hline 1. & First & $01 / 05 / 15$ to $05 / 05 / 15$ \\
\hline 2. & Second & $05 / 05 / 15$ to $09 / 05 / 15$ \\
\hline 3. & Third & $09 / 05 / 15$ to $13 / 05 / 15$ \\
\hline 4. & Fourth & $13 / 05 / 15$ to $17 / 05 / 15$ \\
\hline 5. & Fifth & $17 / 05 / 15$ to $21 / 05 / 15$ \\
\hline 6. & Sixth & $21 / 05 / 15$ to $25 / 05 / 15$ \\
\hline 7. & Seventh & $25 / 05 / 15$ to $29 / 05 / 15$ \\
\hline
\end{tabular}

temperature, electrical conductivity (EC), oxidation-redox potential (ORP), dissolved oxygen (DO), biochemical oxidation demand $\left(\mathrm{BOD}_{5}\right)$, chemical oxidation demand (COD), salinity, total dissolve solids (TDS) and hardness. Wastewater was analyzed at an interval of 5 days for 30 days and compared with control to assess the treatment potential of E. crassipes, and L. minor.

pH: During the study period when the effluent was treated with Eichhornia and Lemna a decrease in $\mathrm{pH}$ was observed. In control experiment a decrease in $\mathrm{pH}$ was observed from $9.60 \pm 0.03$ to $8.2 \pm 0.01$ from initial to final day of treatment. Maximum decrease of 0.31 unit was observed between $1^{\text {st }}$ to $3^{\text {rd }}$ day of treatment whereas minimum decrease of 0.01 unit was found between $13^{\text {th }}$ to $17^{\text {th }}$ day. During 30 days of treatment total 1.4 unit $\mathrm{pH}$ decrease was observed in control treatment (Fig 1 and Table 3). Eichhornia treatment resulted into change in $\mathrm{pH}$ from $9.6 \pm 0.04$ to $7.6 \pm 0.03$ throughout treatment days. Maximum decrease of 0.86unit was recorded between $1^{\text {st }}$ to $5^{\text {th }}$ day of treatment and minimum decrease of 0.01unit was recorded between $9^{\text {th }}$ to $13^{\text {th }}$ day of treatment. Eichhornia treatment leads to a total drop of 0.20 unit in $\mathrm{pH}$ of wastewater. Lemna treatment showed a decrease in $\mathrm{pH}$ from $9.5 \pm 0.02$ to $7.3 \pm 0.01$. $\mathrm{pH}$ decrease was more or less similar during all 6 assessment periods during treatment days. $\mathrm{pH}$ decrease in this treatment ranged between 0.2 to 0.4 unit between successive assessment periods. Eichhornia treatment showed more $\mathrm{pH}$ decrease compared to Lemna treatment during treatment days. Similar findings were observed by Mahmood et al., 2005 and Dipu et al., 2011.

Electrical Conductivity (EC): During assessment period, EC varied from 4009.0 \pm 9.0 to $3998.0 \pm 5.0$ $\mu \mathrm{S} / \mathrm{cm}$ in control; $4007.0 \pm 4.0$ to $2715.0 \pm 3.0 \mu \mathrm{S} / \mathrm{cm}$ in Eichhornia; and $4000.0 \pm 5.0$ to $1965.0 \pm 5.3$ $\mu \mathrm{S} / \mathrm{cm}$ in Lemna treatment (Fig 2 and Table 3).

Maximum decrease was recorded in Lemna treatment followed by Eichhornia and control. In control, EC showed a maximum decrease of 45.0 $\mu \mathrm{S} / \mathrm{cm}$ during third assessment period, whereas minimum decrease of $17.0 \mu \mathrm{S} / \mathrm{cm}$ was found during $5^{\text {th }}$ assessment period treatment. In Eichhornia treatment decrease in EC was fluctuated between 94.0 to $258.0 \mu \mathrm{S} / \mathrm{cm}$ among all assessment periods. Maximum decrease of $258.0 \mu \mathrm{S} / \mathrm{cm}$ was observed in third assessment period whereas minimum decrease of $94.0 \mu \mathrm{S} / \mathrm{cm}$ was recorded during last assessment period of the treatment. Lemna treatment provided better results in terms of EC decrease during entire treatment period. Maximum decrease of $368.0 \mu \mathrm{S} / \mathrm{cm}$ was observed during sixth assessment period. Similarly, Minimum EC reduction of $220.00 \mu \mathrm{S} / \mathrm{cm}$ was recorded in second assessment period $\left(5^{\text {th }}\right.$ to $9^{\text {th }}$ May, 2015). Average EC decrease of $6.8,43.1$ and $67.8, \mu \mathrm{S} / \mathrm{cm} /$ day was observed in Control, Eichhornia and Lemna treatment.

Among all three treatments Lemna showed maximum reduction in EC followed by Eichhornia and Control. EC reduction occurs as result of nutrient uptake of macrophytes and it suggests that Lemna has a better nutrient uptake potential compared to Eichhornia. Electrical Conductivity reflects the amount of ions in waste water as in the phytoremediation ions are absorbed by plants growing in waste water, therefore a decrease in EC was observed during study period. The drastic decrease in electrical conductivity values by growing L. minor in paper mill effluent might be 
Treatment of industrial waste water using Water hyacinth

due to absorption of pollutants by plants. Similar kinds of reports were also obtained by Mahmood et al., 2005; Selvarathi and Ramasubramanian 2010 on working with Eichhornia species. These authors reported $55.71 \%$ reduction of conductivity after 12 days of treatment period.

Oxidation-Redox potential (ORP): ORP increased from $-151.9 \pm-6.3$ to $-113.9 \pm-4.4 \mathrm{mV}$ in control, $-151.9 \pm-6.2$ to $-80.5 \pm-2.3 \mathrm{mV}$ in Eichhornia, and $-148.4 \pm 5.5$ to $-37.6 \pm-1.5 \mathrm{mV}$ in Lemna treatment during treatment days (Fig 3 and Table 3). ORP reduction rate was observed as 25.0 , 47.0 and $74.7 \mathrm{mV}$ in control, Eichhornia and Lemna treatment respectively thorough the treatment days. Average ORP change of $-1.3,-2.4$ and $-3.7 \mathrm{mV} /$ day was observed in control, Eichhornia and Lemna treatment during treatment days. In control treatment, maximum ORP increase of $-8.0 \mathrm{mV}$ was observed in first, second and third assessment treatment each, while minimum increase of -3.0 $\mathrm{mV}$ was recorded on $6^{\text {th }}$ assessment period. In Eichhornia treatment, maximum increase of -19.5 $\mathrm{mV}$ was recorded in first assessment period whereas minimum ORP increase $-3.1 \mathrm{mV}$ was observed in $6^{\text {th }}$ assessment period. Increase in ORP value with time reflects the oxidation of organic matter present in waste water due to microbial and macrophytes.

Total dissolved solids (TDS): TDS concentration dropped from $2650.0 \pm 8.0$ to $2252.0 \pm 7.0 \mathrm{mg} / \mathrm{L}$ in control, $2650.0 \pm 10$ to $1192.0 \pm 8.0 \mathrm{mg} / \mathrm{L}$ in Eichhornia and $2678.0 \pm 5.0$ to $1205.0 \pm 8.0 \mathrm{mg} / \mathrm{L}$ in Lemna treatment during treatment period. TDS removal of $15.0 \%$ was achieved by control treatment whereas $55.0 \%$ removal was observed in both Eichhornia and Lemna treatments during assessment period (Fig 4 and Table 3). Control treatment showed 37.0 to $87.0 \mathrm{mg} / \mathrm{L}$ of TDS removal between two consecutive assessment periods. Highest TDS removal was observed between $2^{\text {nd }}$ and $3^{\text {rd }}$ assessment period. Eichhornia treatment, showed high fluctuations in TDS removal between two consecutive treatment periods compared to control treatment. Maximum TDS removal of $469.0 \mathrm{mg} / \mathrm{L}$ was recorded in second assessment period whereas minimum removal of $1.0 \mathrm{mg} / \mathrm{L}$ was recorded in $7^{\text {th }}$ assessment period. After $17^{\text {th }}$ day of treatment TDS removal rate dropped down significantly because Eichhornia plant could not survive afterwards. Lemna treatment showed consistent results in terms of TDS removal between two consecutive assessment periods. TDS removal fluctuated between 191.0 to $227.0 \mathrm{mg} / \mathrm{L}$ between two consecutive assessment periods. TDS reflects the Total Dissolved Solids in the waste water which are up taken by plants and used for their own growth (Greongerg et al., 1995), therefore we have observed a decrease in TDS with time during study period. A more or less similar trend was observed by Mishra et al., 2013.

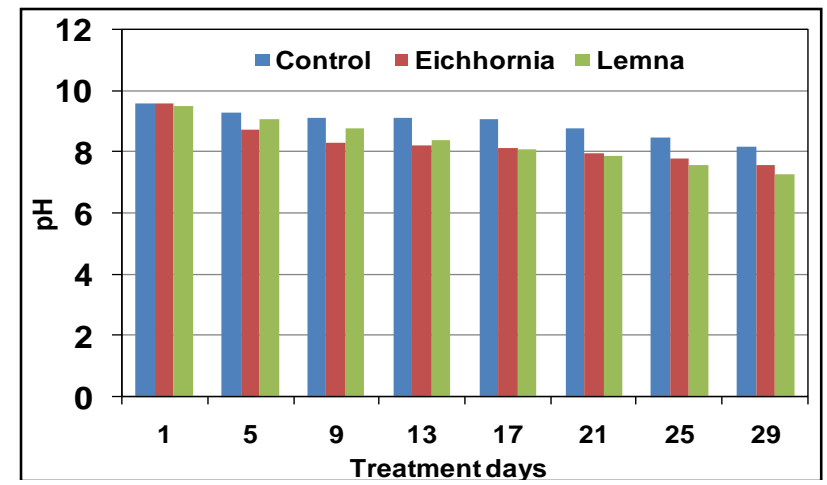

Fig 1. Changes in pH level in control, Eichhornia and Lemna treatment during study period.

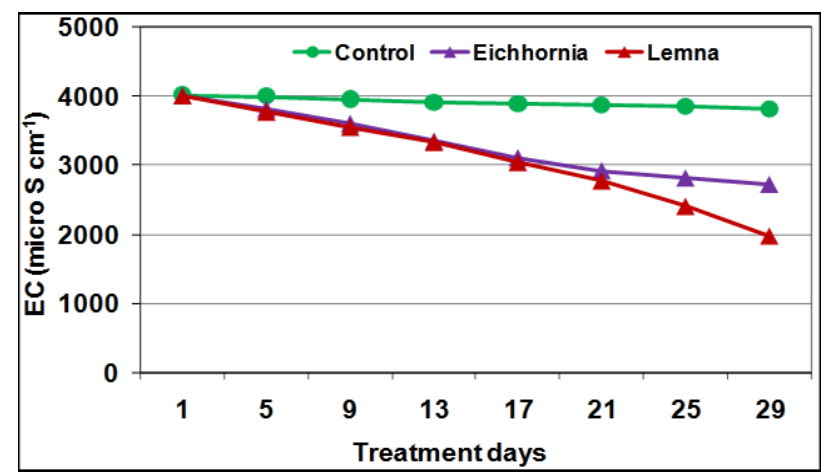

Fig 2. Changes in EC level in control, Eichhornia and Lemna treatment during study period.

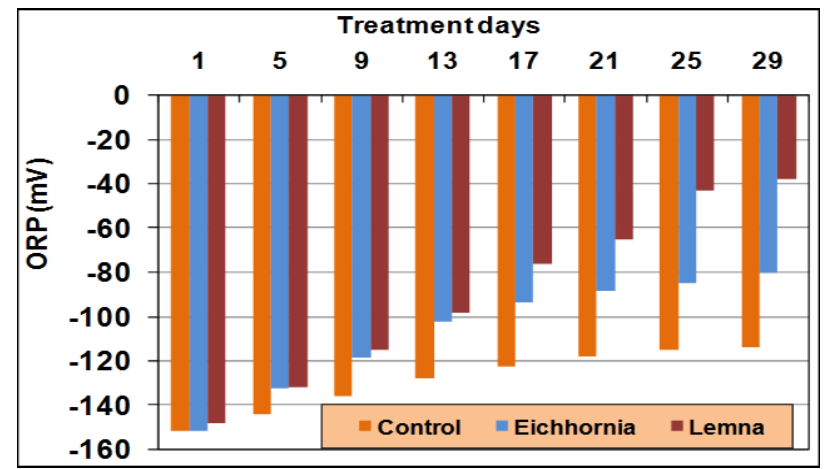

Fig 3. Changes in ORP level in control, Eichhornia and Lemna treatment during study period. 
Salinity: Salinity represents all dissolved salts in the wastewater. Salinity showed a drop from $2650.0 \pm 7.0 \mathrm{mg} / \mathrm{L}$ to $2384.0 \pm 6.0 \mathrm{mg} / \mathrm{L}$ in control, $2450.0 \pm 9.0 \mathrm{mg} / \mathrm{L}$ to $1029.0 \pm 5.0 \mathrm{mg} / \mathrm{L}$ in Eichhornia and $2453.0 \pm 6.0 \mathrm{mg} / \mathrm{L}$ to $600.0 \pm 5.0$ $\mathrm{mg} / \mathrm{L}$ in Lemna treatment (Fig 5 and Table 3). In control treatment, highest salinity removal of 50.0 $\mathrm{mg} / \mathrm{L}$ was achieved during first assessment period whereas lowest salinity removal was recorded during $7^{\text {th }}$ assessment period. Eichhornia treatment showed large fluctuations in salinity removals during assessment periods (27.0-474.0 mg/L ). Lemna treatment also provided better removals for salinity compared to Eichhornia treatment Removal efficiency fluctuated between $11-20 \%$ in assessment periods. Highest removal was achieved during $6^{\text {th }}$ assessment period. Macrophytes have a tendency to absorb dissolved salts present in waste water through their roots, therefore there is a decrease in salinity during study period which reflects that macrophytes absorbed the dissolved salts efficiently from the waste water.

Biochemical Oxygen Demand (BOD $)_{5}$ : In control, Eichhornia and Lemna treatments BOD value showed a drop from $356.0 \pm 3.4$ to $293.0 \pm 4.0$, $356.0 .0 \pm 5.3$ to $231.0 \pm 4.2$ and $361.0 \pm 3.7$ to $174.0 \pm 4.5 \mathrm{mg} / \mathrm{L}$ respectively (Fig 6 and Table 3 ). Total BOD removal during treatment period was recorded as; $17.8 \%$ for control, $35.0 \%$ for Eichhornia and $51.8 \%$ for Lemna. In addition, Average BOD removal per day during assessment period was found as 2.1, 4.2 and $6.2 \mathrm{mg} / \mathrm{L}$ in control, Eichhornia and Lemna respectively. Highest BOD removal was achieved by Lemna followed by Eichhornia and control. Control treatment was resulted in maximum BOD removal of $15.0 \mathrm{mg} / \mathrm{L}$ during $7^{\text {th }}$ assessment period and a minimum removal of $1.0 \mathrm{mg} / \mathrm{L}$ during $5^{\text {th }}$ assessment period. Eichhornia treatment showed fluctuated BOD removal among different assessment periods; maximum of $33.3 \mathrm{mg} / \mathrm{L}$ between $1^{\text {st }}$ to $5^{\text {th }}$ day of treatment and minimum of $4.0 \mathrm{mg} / \mathrm{L}$ between $21^{\text {st }}$ to $25^{\text {th }}$ day of treatment. Lemna treatment also showed higher BOD removal during treatment period. BOD removal rate fluctuated between 17.0 to $46.0 \mathrm{mg} / \mathrm{L}$ between consecutive assessment periods. Higher removal rate $(46 \%)$ was observed in $26^{\text {th }}$ to $30^{\text {th }}$ day of treatment. The duckweed contribution for the removal of organic material is due to their ability to direct use of simple organic compounds. BOD is the amount of oxygen required by microorganisms for degradation of organic matter present in waste water. The microbes convert organic matter into simpler nutrients which are further absorbed by macrophytes. A decrease in BOD was observed during study period which shows that microorganisms effectively degraded the organic matter present in waste water (Bhutianin et al., 2016).

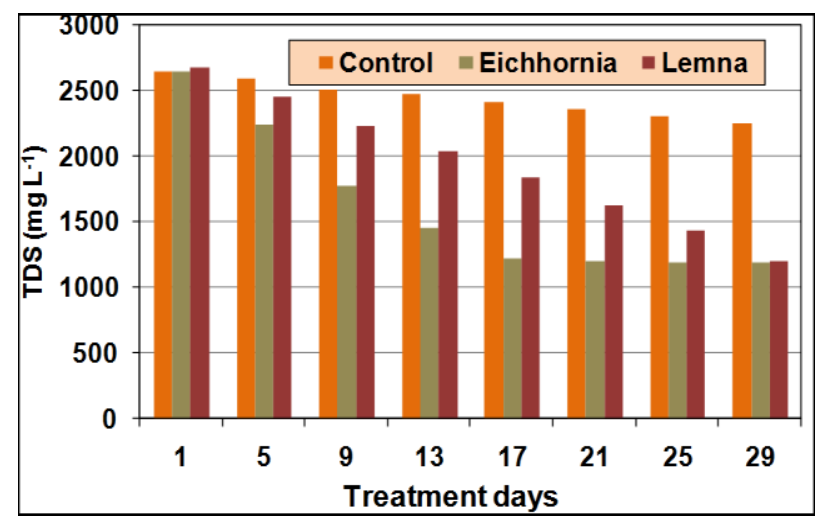

Fig 4. Changes in TDS level in control, Eichhornia and Lemna treatment during study period.

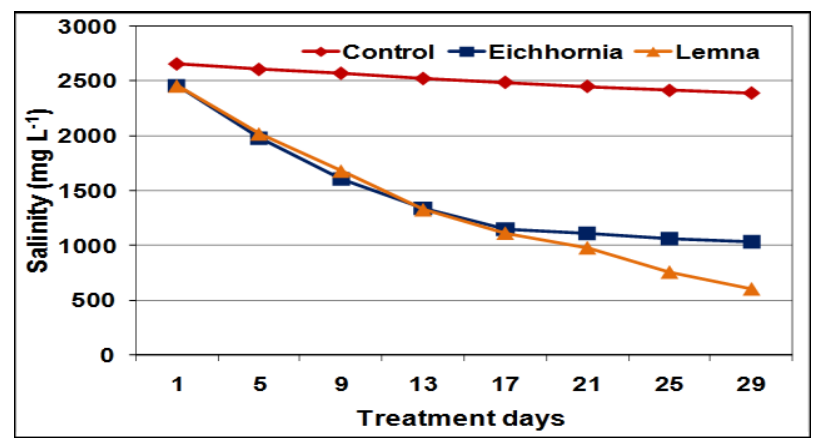

Fig 5. Changes in Salinity level in control, Eichhornia and Lemna treatment during study period.

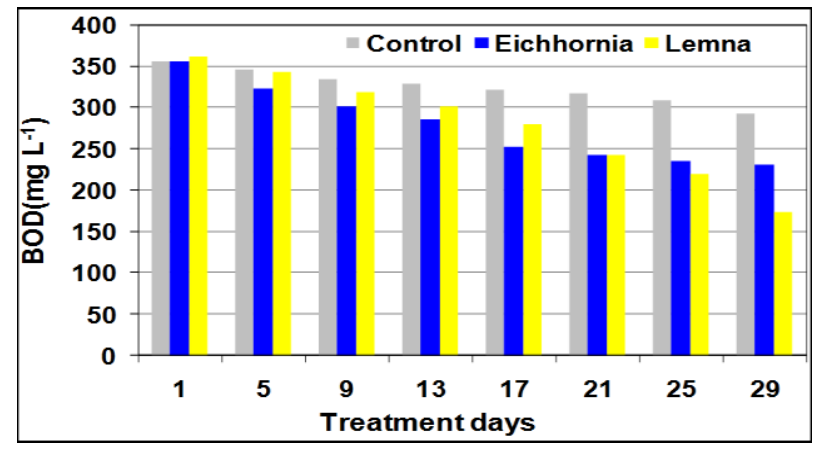

Fig 6. Changes in BOD level in control, Eichhornia and Lemna treatment during study period. 
Chemical Oxygen Demand (COD): Chemical oxygen demand is amount of oxygen required to oxidize the organic and inorganic pollution present in waste water. Control treatment showed a decrease in COD value from 519.0 \pm 7.0 to $436.0 \pm 4.0 \mathrm{mg} / \mathrm{L}$ throughout the assessment period (Fig 7 and Table 3). COD removal rate in control treatment was recorded as $16.0 \%$. Average COD removal was recorded as $2.8 \mathrm{mg} / \mathrm{L}^{\prime} \mathrm{day}^{-}$. COD removal fluctuated between 7.0 to $25.0 \mathrm{mg} / \mathrm{L}$ within assessment periods. Maximum removal was recorded in $5^{\text {th }}$ assessment period while minimum removal was observed in $7^{\text {th }}$ assessment period. Eichhornia treatment provided a decrease in COD from $519.0 \pm 4.9$ to $321.0 \pm 6.5 \mathrm{mg} / \mathrm{L}$ during treatment. Total COD removal in this treatment was observed as $38.2 \%$ and average COD removal was recorded as $6.6 \mathrm{mg} / \mathrm{L} /$ day during assessment period. Maximum COD removal of $49.0 \mathrm{mg} / \mathrm{L}$ was observed between $4^{\text {th }}$ assessment periods. In Lemna treatment, COD value decreased from 516 \pm 7.0 to $361 \pm 4.0 \mathrm{mg} / \mathrm{L}$. A more or less similar trend in COD reduction was observed by Deshmukh et al., 2013. Presence of plants in wastewater can deplete dissolved $\mathrm{CO}_{2}$ during the period of high photosynthetic activity. This photo-synthetic activity increases the dissolved oxygen of water, thus creating aerobic conditions in wastewater which favour the aerobic bacterial activity to reduce the BOD and COD (Reddy, 1983).

Dissolved Oxygen (DO): In control, Eichhornia and Lemna treatment, dissolved oxygen concentration dropped from $1.84 \pm 0.02$ to $1.24 \pm 0.01$ $\mathrm{mg} / \mathrm{L}, 1.82 \pm 0.11$ to $1.32 \pm 0.03 \mathrm{mg} / \mathrm{L}$ and $1.83 \pm 0.04$ to $1.43 \pm 0.06 \mathrm{mg} / \mathrm{L}$ respectively (Fig 8 and Table 3 ). Total DO decrease was assessed as 32.6, 27.5 and $20.6 \%$ in control, Eichhornia and Lemna treatment respectively during treatment period. Maximum DO drop was observed in control followed by Eichhornia and Lemna. Average daily decrease in DO was observed as $0.1,0.04$ and $0.02 \mathrm{mg} / \mathrm{L} /$ day control, Lemna and Eichhornia respectively. Microorganisms consume DO during degradation of organic matter in waste water, we have observed a decrease in DO level in all treatments, and however this decrease was less in the treatment of Eichhornia and Lemna. This suggests that during phytoremediation aquatic plants help in enriching the waste water with oxygen by photosynthesis process. The results favours the findings of
Mangas-Ramirez and Elias-Gutierrez, 2004 and Perna and Burrows, 2005 but are opposites to Darr et al., 2011 and Shah et al., 2010.

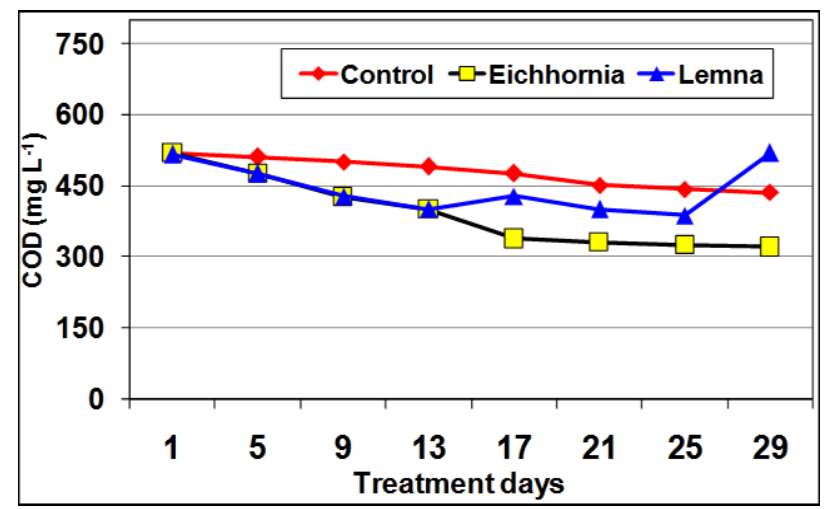

Fig 7. Changes in COD level in control, Eichhornia and Lemna treatment during study period.

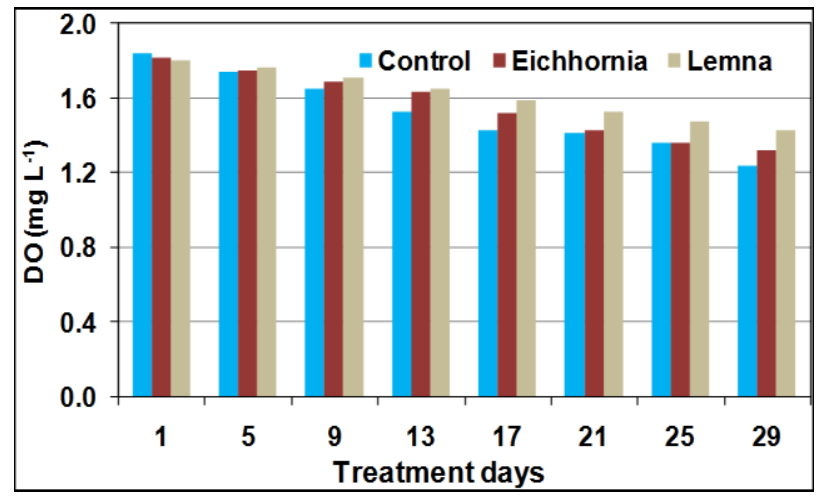

Fig 8. Changes in DO level in control, Eichhornia and Lemna treatment during study period.

Hardness (as $\left.\mathrm{CaCO}_{3}\right)$ : Hardness was decreased in all treatments during treatment period i.e. $150.0 \pm 4.5$ to $111.0 \pm 4.2 \mathrm{mg} / \mathrm{L}$ in control; $152.0 \pm 3.6$ to $106.0 \pm 4.6 \mathrm{mg} / \mathrm{L}$ in Eichhornia and $147.0 \pm 4.1$ to 89.6.0 $\pm 4.2 \mathrm{mg} / \mathrm{L}$ in Lemna treatment (Fig 10 and Table 3). Total Hardness removal was found highest $(39.0 \%)$ in Lemna treatment followed by $30.3 \%$ in Eichhornia and $26.0 \%$ in control. Average hardness removal was observed as; 1.3 $\mathrm{mg} / \mathrm{L} /$ day in control, $1.5 \mathrm{mg} / \mathrm{L}$ in Eichhornia, and $1.9 \mathrm{mg} / \mathrm{L}$ in Lemna treatment. Removal range between successive assessment periods varied from 3.0 to $8.0 \mathrm{mg} \mathrm{L}^{-1}$ in control, 3.0 to $9.0 \mathrm{mg} / \mathrm{L}$ in Eichhornia, and 3.4 to $11.0 \mathrm{mg} / \mathrm{L}$ in Lemna treatment. Similar trend of hardness removal was also observed by Fonseka and Amarasinghe, 2016 and Shah et al., 2010. 
Table 3. Showing the changes in physico-chemical properties of industrial effluent control treatment and after the treatment with Eichhornia and Lemna.

\begin{tabular}{|c|c|c|c|c|c|c|c|c|c|c|c|}
\hline & & $\mathbf{p H}$ & $\begin{array}{l}\text { EC } \\
\left(\mu \mathrm{s} \mathrm{cm}^{-1}\right)\end{array}$ & $\begin{array}{l}\text { ORP } \\
(\mathrm{mV})\end{array}$ & $\begin{array}{l}\text { Do } \\
\left(\mathrm{mg} \mathrm{L}^{-1}\right)\end{array}$ & $\begin{array}{l}\text { temp. } \\
\left({ }^{0} \mathrm{C}\right)\end{array}$ & $\begin{array}{l}\text { TDS } \\
\text { (mg L-1) }\end{array}$ & $\begin{array}{l}\text { BOD } \\
\text { (mg L-1) }\end{array}$ & $\begin{array}{l}\text { COD } \\
(\mathrm{mg} \mathrm{L-1)}\end{array}$ & $\begin{array}{l}\text { Hardness } \\
(\mathrm{mg} L-1)\end{array}$ & $\begin{array}{l}\text { Salinity } \\
\text { (mg L-1) }\end{array}$ \\
\hline \multirow{3}{*}{$1 / 5 / 2015$} & Control & 9.6 & 4009 & -151.9 & 1.84 & 25.3 & 2650 & 356 & 519 & 150 & 2650 \\
\hline & Eichhornia & 9.6 & 4007 & -151.9 & 1.82 & 25.3 & 2650 & 356 & 519 & 152 & 2450 \\
\hline & Lemna & 9.5 & 4000 & -148.4 & 1.8 & 25.3 & 2678 & 361 & 516 & 147 & 2453 \\
\hline \multirow{3}{*}{$5 / 5 / 2015$} & Control & 9.29 & 3988 & -144.0 & 1.74 & 25.9 & 2600 & 345 & 510 & 143 & 2600 \\
\hline & Eichhornia & 8.74 & 3818 & -132.4 & 1.75 & 26.3 & 2245 & 323 & 476 & 143 & 1976 \\
\hline & Lemna & 9.1 & 3765 & -132.3 & 1.76 & 26.2 & 2456 & 342 & 476 & 136 & 2015 \\
\hline \multirow{3}{*}{$9 / 5 / 2015$} & Control & 9.13 & 3945 & -136.0 & 1.65 & 28.4 & 2513 & 334 & 501 & 135 & 2565 \\
\hline & Eichhornia & 8.3 & 3603 & -118.9 & 1.69 & 28.3 & 1776 & 301 & 427 & 136 & 1603 \\
\hline & Lemna & 8.8 & 3545 & -115.2 & 1.71 & 27.7 & 2234 & 318 & 428 & 126 & 1675 \\
\hline \multirow{3}{*}{$13 / 5 / 2015$} & Control & 9.11 & 3900 & -128.0 & 1.53 & 25.3 & 2476 & 329 & 490 & 127 & 2517 \\
\hline & Eichhornia & 8.23 & 3345 & -102.2 & 1.63 & 24.4 & 1454 & 285 & 400 & 128 & 1335 \\
\hline & Lemna & 8.4 & 3323 & -98.4 & 1.65 & 24.4 & 2043 & 301 & 401 & 118 & 1323 \\
\hline \multirow{3}{*}{$17 / 5 / 2015$} & Control & 9.1 & 3882 & -123.0 & 1.43 & 25.6 & 2416 & 321 & 476 & 122 & 2482 \\
\hline & Eichhornia & 8.14 & 3105 & -93.6 & 1.52 & 25.7 & 1225 & 252.4 & 338 & 119 & 1145 \\
\hline & Lemna & 8.1 & 3035 & -76.4 & 1.59 & 25.9 & 1845 & 280 & 428 & 109 & 1109 \\
\hline \multirow{3}{*}{ 21/5/2015 } & Control & 8.8 & 3865 & -118.0 & 1.41 & 24.4 & 2365 & 317 & 451 & 117 & 2445 \\
\hline & Eichhornia & 7.96 & 2916 & -88.3 & 1.43 & 23 & 1201 & 243 & 331 & 116 & 1103 \\
\hline & Lemna & 7.9 & 2765 & -65.4 & 1.53 & 23.7 & 1632 & 242 & 400 & 99 & 976 \\
\hline \multirow{3}{*}{$25 / 5 / 2015$} & Control & 8.5 & 3845 & -115.0 & 1.36 & 27.5 & 2312 & 308 & 443 & 114 & 2408 \\
\hline & Eichhornia & 7.82 & 2809 & -85.2 & 1.36 & 27.3 & 1193 & 235 & 325 & 111 & 1056 \\
\hline & Lemna & 7.6 & 2397 & -43.3 & 1.47 & 27.8 & 1432 & 220 & 388 & 93 & 754 \\
\hline \multirow{3}{*}{$29 / 5 / 2015$} & Control & 8.2 & 3806 & -113.9 & 1.24 & 28.3 & 2252 & 293 & 436 & 111 & 2384 \\
\hline & Eichhornia & 7.6 & 2715 & -80.5 & 1.32 & 27.5 & 1192 & 231.5 & 321 & 106 & 1029 \\
\hline & Lemna & 7.3 & 1965 & -37.6 & 1.43 & 27.1 & 1205 & 174 & 361 & 89.6 & 600 \\
\hline
\end{tabular}




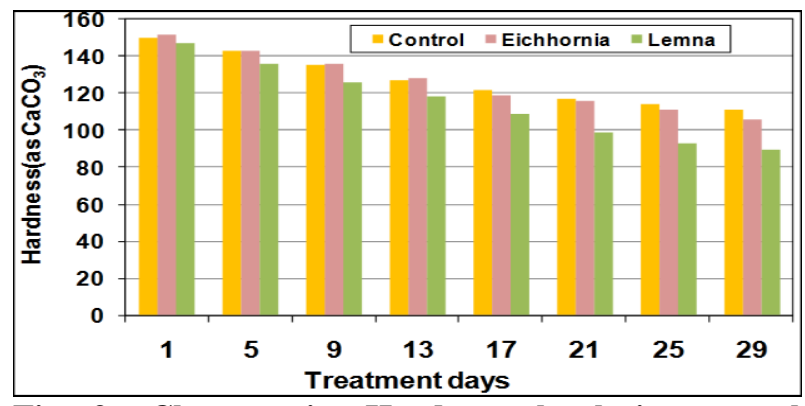

Fig 9. Changes in Hardness level in control, Eichhornia and Lemna treatment during study period.

\section{Conclusion}

Phytoremediation, an eco-friendly concept, involves the use of plants to clean-up the contaminated environments. Beside all the technologies present today's the use of foliage plants and trees may be the best means of improving the water quality. An interdisciplinary technological approach that used aquatic plants are appropriate for the treatment of wastewater due to their tremendous capacity of absorbing nutrients and heavy metals from wastewater to bring down the pollution load. Due to rapid growth on wide range of $\mathrm{pH}$ and tolerance to cold climate grow throughout the year but aquatic plants, such as water hyacinth, can only grow in summer, Duckweed appear to be better alternative for wastewater treatment.This study revealed that the duckweed (L.minor) showed a better lead removal than others from polluted water and may be helpful in research studies and phytoremedial approaches. Present study shows that phytoremediation is promising technology for treatment of low BOD industrial waste water. In Eichhornia treatment, maximum ORP drop of $-19.5 \mathrm{mV}$ was recorded in first assessment period. Eichhornia treatment showed large fluctuations in salinity removals during assessment periods (27.0-474.0 mg/L). Average BOD removal per day during assessment period was found as 2.1, 4.2 and $6.2 \mathrm{mg} / \mathrm{L}$ in control, Eichhornia and Lemna respectively. Highest BOD removal was achieved by Lemna followed by Eichhornia and control.

\section{References}

APHA, AWWA WPCF (2012). Standard methods for the examination of water and waste water. American Public Health Association, Washington $14^{\text {th }}$ Edition. N. York. 193.
Aoi, T. and Hayashi, T. (1996). Nutrient removal by water lettuce (Pisitiastratiotes). Water Science and Technology, 34: 407-412.

Bartodziej, W. and Weymouth, G. (1995). Waterbird abundance and activity on water-hyacinth and Egeriain the St-Marks River, Florida. Journal of Aquatic Plant Management, 33: 19-22.

Bhutiani, R., Khanna,D. R., Shubham and Ahamad, F. 2016. Physico-chemical analysis of Sewage water treatment plant at Jagjeetpur, Haridwar, Uttarakhand. Environ. Cons. Jour., 17(3): 133-142.

Bhutiani, R., Khanna,D. R., Tyagi, V. and Ahamad, F. 2016. Utilisation of free floating macrophytes for milk process unit wastewater treatment. Environ. Cons. Jour., 17(1\&2): 1387-193.

Borkar, R. P., Gulhane, M. L., and Kotangale, A. J. 2013. "Moving Bed Biofilm Reactor - A New Perspective in Wastewater Treatment", Journal of Environmental Science, Toxicology and Food Technology, 6(6): 15-21.

Brendonck, L., Maes, J., Rommens, W., Dekeza, N., Nhiwatiwa, T., Barson, M., Callebaut, V., Phiri, C., Moreau, K., Gratwicke, B., Stevens, M., Alyn, N., Holsters, E., Ollevier, F., and Marshall, B. 2003. The impact of water hyacinth (Eichhorniacrassipes) in a eutrophic subtropical impoundment (Lake Chivero, Zimbabwe). II. Species diversity. Archiv Fur Hydrobiologie, 158: 389-405.

Cossu, R., Haarstad, K., Lavagnolo, M. C. and Littarru, P. 2001. Removal of municipal solid waste COD and NH4-N by phyto-reduction: A laboratory-scale comparison of terrestrial and aquatic species at different organic loads. Ecological Engineering, 16: 459-470.

Cunningham, S. D., Shann, J. R., Crowley, D. E., Anderson, T. A. 1997. Phytoremediation of contaminated water and soil. In: Kruger E.L., Anderson, T.A., Coats, J.R., (eds.) Phytoremediation of soil and water contaminants. ACS symposiumseries 664. American Chemical Society Washington, D.C., 2-19.

Dar, S. H., Kumawat, D. M., Singh, N. and Wani, K. A. 2011. Sewage treatment potential of water hyacinth (Eichhornia crassipes)., Res. J. Environ. Sci., 5(4): 377-385.

Deshmukh , A. A., Bandela, N. N., Chavan, J. R. and Nalawade, P. M. 2013. Studies on Potential Use of Water Hyacinth, Pistia and Azolla for Municipal Waste Water Treatment. Environment, 3(11): 226-228.

DIN, 2000. Duckweed growth inhibition test: Determination of the non-poisonous effect of water constituent and waste water to duck weed (Lemna minor, Lemnagibba), DeutschesInstitutfürNormunge.V. durchBeuthVerlag, Berlin: 19. 
Dipu, S., Kumar, A. A and Thanga, V. S. G. 2011. Phytoremediation of dairy effluent by constructed wetland technology., Environmentalist, 31: 263-278.

Eberius, M. 2001. Assessment of inhibition values and comprehensive analysis of biotests. LemnaTec GmbH, Würselen, http://www.lemnatec.com/Literatur/LT003.pdf

Ensley, B. D. 2000. Rationale for the Use of Phytoremediation. Phytoremediation of toxic metals: Using plants to clean-up the environment. John Wiley Publishers: New York.

EPA, 1996. Aquatic Plant Toxicity Test Using Lemna spp.: Tiers I and II - OPPTS 850.4400. United States Environmental Protection Agency Prevention,Pesticides and Toxic Substances Unit, New York: 9.

Flathman, P. E. and Lanza, G. R. 1998. Phytoremediation: current views on an Emerging Green Technology, Journal of Soil Contamination, 7(4): 415-432.

Fonseka, S. and Amarasinghe, D. 2016. Characterization of ground water hardness with special reference to Polpithigama Divisional Secretariat Area in Kurunegala district and potential use of plants to reduce water Hardness. Thesis submitted to department of Botany and the department of Chemistry, University of Kelaniya.

Gibbons, M., Gibbons, Jr. H. and Sytsma, M. 1994. A Citizen's Manual for Developing Integraed Aquatic Vegetation Management Plans. inWater Environmental Services. Available Water Environmental Services.

Giraldo, E. and Garzon, A. 2002. The potential for water hyacinth to improve the quality of Bogota River water in the Muña Reservoir: comparison with the performance of waste stabilization ponds. Water Science and Technology, 42: $103-110$.

Greenfield, B. K., Siemering, G. S., Andrews, J. C., Rajan M., Andrews, S. P. and Spencer, D. F. 2007. Mechanical shredding of water hyacinth (Eichhorniacrassipes): Effects on water quality in the Sacramento-San Joaquin River Delta, California. Estuaries and Coasts, 30: 627-640.

Greongerg, A. E., Connors, J. E., Jinkins, D. and Fransons, M. A. 1995. Standard methods for the examination of water and waste water (15th ed., pp. 199-209). Washington DC: American Public Health Association, APHA.

Hellmann, J. J., Byers, J. E., Bierwagen, B. G. and Dukes, J. S. 2008. Five potential consequences of climate change for invasive species. Conservation Biology, 22: 534-543.

ISO. 2001. Water quality - Determination of the toxic effect of water constituents and waste water to duckweed (Lemna minor) - Duckweed growth inhibition test ISO TC 147/SC $5 \mathrm{~N}$, International Organisation for Standardisation: Geneva, 26.
Khanna D. R. and Bhutiani R. 2008. Laboratory manual of water and Waste water Analysis. Daya Publishing House New Delhi -110002.

Kumar, V., Chopra, A. K. 2016. Reduction of pollution load of paper mill effluent by phytoremediation technique using water caltrop (Trapa natans L.). Cogent Environmental Science, 2: 1153216.

Kumar, V., Chopra, A. K., Singh, J., Thakur, R. K., Srivastava, S., and Chauhan, R. K. 2016. Comparative assessment of phytoremediation feasibility of water caltrop (Trapa natans L.) and water hyacinth (Eichhornia crassipes Solms.) using pulp and paper mill effluent. Archives of Agriculture and Environmental Science, 1(1): 13-21.

Kumar, V., Chopra, A. K., Singh, J., Thakur, R. K., Srivastava, S. and Chauhan, R. K. 2017b. Comparative assessment of phytoremediation feasibility of water caltrop (Trapa natans L.) and water hyacinth (Eichhornia crassipes Solms.) using pulp and paper mill effluent. Archives of Agriculture and Environmental Science, 1(1): 13-21.

Kumar, V., Singh, J. and Chopra, A. K. 2017a. Assessment of phytokinetic removal of pollutants of paper mill effluent using water hyacinth (Eichhornia crassipes [Mart.] Solms), Environmental Technology, https://doi.org/ 10. 1080/ 09593330.2017.1365944

Les, D. H., Crawford, D. J., Landolt, E., Gabel, J. D. and Kemball, R. T.2002. Phylogeny and systematics of Lemnaceae, the duckweed family. Systematic Botany, 27: 221-240.

Les, D. H., Landolt, E. and Crawford, D. J. 1997. Systematics of the Lemnaceae (duckweeds): inferences from micromolecular and morphological data. Systematics and Evolutionary, 204: 161-177.

Lu, J. B., Wu, J. G., Fu, Z. H. and Zhu, L. 2007. Water hyacinth in China: A sustainability science based management framework. Environmental Management, 40: 823-830.

Mahmood, Q., Zheng, P., Islam, E., Hayat, Y., Hassan, M. J., Jilani, G. 2005. Lab scale studies on water hyacinth (Eichhornia crassipes Marts Solms) for biotreatment of textile waste water. Caspian Journal of Environmental Science, 3: 83-88.

Mangas-Ramirez, E. and Elias-Gutierrez, M. 2004. Effect of mechanical removal of water hyacinth (Eichhorniacrassipes) on the water quality and biological communities in a Mexican reservoir. Journal of Aquatic Health and Management: 7161-168.

Martinez Jimenez, M. and Gomez Balandra, M. A. 2007. Integrated control of Eichhorniacrassipesby using insects and plant pathogens in Mexico. Crop Protection, 26: 12341238 . 


\section{Treatment of industrial waste water using Water hyacinth}

Meerhoff, M., Mazzeo, N., Moss, B. and Rodriguez-Gallego, L. 2003. The structuring role of freefloating versus submerged plants in a subtropical shallow lake. Aquatic Ecology, 37: 377-391.

Mishra, S., Mohanty, M., Pradhan, C., Patra, H. K., Das, R., and Sahoo. S. 2013. Physico-chemical assessment of paper mill effluent and its heavy metal remediation using aquatic macrophytes - a case study at JK Paper mill, Rayagada, India. Environ Monit Assess, DOI 10.1007/s10661-0122873-9, 185:4347-4359.

Mkandawire, M., and Dudel, E. G. 2005a. Accumulation of arsenic in LemnagibbaL. (duckweed) in tailing waters of two abandoned uranium mines in Saxony, Germany. Science of the Total Environment, 336: 81-89.

Mkandawire, M., and Dudel, E. G. 2005b. Assignment of LemnagibbaL. (duckweed) bioassay for in situ ecotoxicity assessment. Aquatic Ecology, 39: 151-165.

OECD, 2002. OECD Guidelines for the testing of Chemicals: Lemnasp. Growth Inhibition Test. 221. Organisation for Economic Corporation and Development, Berlin: 22.

Padmapriya, G., and Murugesan, A. G. 2012. Phytoremediation of various heavy metals $(\mathrm{Cu}, \mathrm{Pb}$ and $\mathrm{Hg})$ from aqueous solution using water hyacinth and its toxicity on plants. International Journal of Environmental Biology, 2(3): 97-103.

Perna, C. and Burrows, D. 2005. Improved dissolved oxygen status following removal of exotic weed mats in important fish habitat lagoons of the tropical Burdekin River floodplain, Australia. Marine Pollution Bulletin, 51: 138148.

Rahel, F. J. and Olden, J. D. 2008. Assessing the effects of climate change on aquatic invasive species. Conservation Biology, 22: 521-533.

Reddy, K. R. 1983. Fate of nitrogen and phosphorus in wastewater retention reservoir containing aquatic macrophytes. J. Environ. Qual., 12: 137- 141.

Rodríguez-Gallego, L. R., Mazzeo, N., Gorga, J., Meerhoff, M., Clemente, J. C. F. S., Lacerot, G., García, J. and Quintans, F. 2004. The effects of an artificial wetland dominated by freefloating plants on the restoration of a subtropical, hypertrophic lake. Lakes \& Reservoirs, 9: 203215 .

Rommens, W., Maes, J., Dekeza, N., Inghelbrecht, P., Nhiwatiwa, T., Holsters, E., Ollevier, F., Marshall, B. and Brendonck, L. 2003. The impact of water hyacinth (Eichhorniacrassipes) in a eutrophic subtropical impoundment (Lake Chivero, Zimbabwe). I. Water quality. Archiv Fur Hydrobiologie, 158: 373-388.

Schwitzguebel, J. 2000. Potential of Phytoremediation, an emerging green technology. In: Ecosystem Service and
Sustainable Watershed Management in North China. Proceedings of International Conference, Beijing, P.R. China, August: 23-25.

Selvarathi, P. and Ramasubramanian, V. J. 2010. Phytoremedial effect of Datura metel L. on paper mill effluent and its impact on Physicochemical characteristics of Lycopersicon esculentum Mill. Bioscience Research, 1(2): 94-100.

Shah, R. A., Kumawat, D. M., Singh, N. and Wani, K. A. 2010. Water hyacinth (Eichhornia crassipes) as a remediation tool for dye-effluent pollution., Int. J. Sci. Nature, 1(2): 172178.

Sooknah, R. D., and Wilkie, A. C. 2004. Nutrient removal by floating aquatic macrophytes cultured in anaerobically digested flushed dairy manure wastewater. Ecological Engineering, (22): 27- 42.

Tiwari, S., Dixit, S. and Verma, N. 2007. An effective means of biofiltration of heavy metal contaminated water bodies using aquatic weed Eichhorniacrassipes. Environmental Monitoring and Assessment, 129: 253-256.

Trivedi, R. K. and Goel, P. K. 1986. Chemical and biological methods for water pollution studies. Environmental publications; 1-250.

Troutman, J. P., Rutherford, D. A. and Kelso, W. E. 2007. Patterns of habitat use among vegetationdwelling littoral fishes in the Atchafalaya River Basin, Louisiana. Transactions of the American Fisheries Society, 136: 1063-1075.

UNEP (Undated). Phytoremediation: An Environmentally Sound Technology for Pollution Prevention, Control and Redmediation. An Introductory Guide to Decision-Makers. Newsletter and Technical Publications Freshwater Management Series No. 2 United Nations Environment Programme Division of Technology, Industry, and Economics.

Weis, J. S., and Weis, P. 2004. Metal uptake, transport and release by wetland plants: imploications for phytoremediation and restoration. Environ. Intl, : 685-700.

Wilson, J. R. U., Ajuonu, O., Center, T. D., Hill, M. P., Julien, M. H., Katagira, F. F., Neuenschwander, P., Njoka, S. W., Ogwang, J., Reeder, R. H. and Van, T. 2007. The decline of water hyacinth on Lake Victoria was due to biological control by Neochetina spp. Aquatic Botany, 87: 90-93.

Zimmels, Y., Kirzhner, F. and Malkovskaja, A. 2007. Advanced extraction and lower bounds for removal of pollutants from wastewater by water plants. Water Environment Research, 79: 287-296. 